\title{
Performance Issues of CMS in Automobile Industries using Computer Simulation
}

\author{
J. H. Bhangale \\ Ph.D. Scholar, \\ LIT, Nagpur \\ RTM Nagpur University, India
}

\author{
A. M. Mahalle \\ Phd, Reader, \\ LIT, Nagpur \\ RTM Nagpur University, India
}

\begin{abstract}
Today, every company wants to curtail its expenses. Productivity being the main criteria, the daily demand plays a major role and based on this production takes place. This paper shows how cellular concept has contrasting approach in India and Japan and also, it gives detailed information about cell and cellular layout. Also, it consists of problem identification in the existing layout, objectives and methodology followed to achieve the objectives .In India, few companies like TVS, Maruti etc. have implemented it and other few are in a way of implementation (like Mahindra \& Mahindra).

A "Cell" is a collection of dissimilar machines or processes, located closely together in a sequential operation manner and dedicated to a set of a similar part and product. Cell is that in which two or more machine should be arrange such that receiving and shipping should be present at same location. Each machine has fix position and dissimilar machines are arranged in a cell so, the layout is known as cellular layout. CMS emphasis on : 1)To reduce through put time of the component, 2)To increase the target of manufacturing component and completion of target as per demand, 3)To maximize manpower utilization, 4) To minimize space utilization, 5)To reduce investment per unit output, 6)To reduce manpower requirement, 7)To improve Material Flow Control, 8)Cell Design, 9)Design Standardization .
\end{abstract}

\section{Keywords}

Cell Simulation, CMS implementation,Virtual Manufacturing, Re-engineering.

\section{INTRODUCTION}

The implementation of cellular manufacturing has grown rapidly during the past two decades. The process of achieving a cellular manufacturing system is called cell formation problem. The cell formation problem in CMS is the decomposition of the manufacturing systems into cells. Part families are identified such that they are fully processed within the cell. The cells are formed to capture the advantages of group technology such as reduced set-up times, reduced in process inventories, improved product quality, shorter lead times, reduced tool requirements, improved productivity and better overall control of operations[1].For competing in 21st century market, Mahindra \& Mahindra is planning to switch over to "Cellular Layout" in which manufacturing process is carried out by proper arrangement of machines. Due to these characteristics, Cellular layout is most popular in Japan. Restructuring of existing layout by using CMS is the key solution for productivity improvement of Automobile industries. This paper reflects the major obstacles for CMS implementation and suggests guideline for proposed solution.

\section{SIMULATION APPROACH}

\subsection{Issues related to CMS implementation}

-Identification of part families

- Identification of cell equipment and allocation of families to equipment (or vice versa)

- Cell Independence: part operation sequences do not span multiple cells

- Cell Flexibility:

1. Internal routing flexibility : to process parts on alternate machines inside a cell

2. External routing flexibility: the ability to release parts to alternate cells

3. Process flexibility: the ability of the cells to accommodate new parts

- Flow Control:

1. Material obsolescence

2. Material costs

3. Indirect labour

4. Inter-departmental stores

- Cell Design :

1. Difficult load balancing

2. Possible low utilization of non-key machines

3. Difficulty in batch size selection

4. Bottleneck machines

- Invalid Assumptions:

1. Job satisfaction may fail due to reduced variety of job processed in cells

2. Stocks and WIP are high, as machines require their own pool rather than sharing the common pool as in functional layout

3. Production control coordinating the various cells is difficult.

\subsection{Problems in CMS}

As per considering the design of CMS, the problems can mainly classified into two types. They are 'Structural' related to system structure and 'Operational' related to system operation. Besides the design issues there are number of issues to be tackled before the implementation of Cellular System such as 'Organizational', 'Human Behaviour', and 'Applicability'. But as the project work deals with the design issues of CMS, the other problems are not considered in detail[12].

\subsubsection{Structural issues}

1. Selection of part populations and grouping of parts into families

2. Selection of machine and process populations and grouping of these into cells

3. Selection of tools, fixtures, and pallets 
4. Selection of material handling equipment

5. Choice of equipment layout

Likewise, typical problems related to the operation of the Cellular System are:

1. Formulation of maintenance policies

2. Formulation of inspection policies

3. Design of procedures for production planning, scheduling, and control

4. Design of jobs and formulation of job responsibilities for operators and support staff

5. Design of reporting mechanisms and reward systems

6. Outline of procedures for interfacing with the remaining manufacturing system (in terms of work flow and information: whether computer controlled or not).

Every decision during the design process whether related to structure or operation, affects system cost and performance. Perhaps the first and important problem faced in cell design relates to cell formation (CF), i.e. the identification and selection of parts and machines for Cellular Manufacturing. Considerable research has gone into this phase and several more or less formalized procedures have been developed over the years. In short, two distinct approaches to this problem can be discerned-those based on part characteristics and those based on production methods. Part-oriented techniques approach cell design from the characteristics of the parts involved and range from simple identification techniques, such as use of part name or part function, to more sophisticated approaches using GT oriented classification and coding systems. Production methods rely on the routings (also called process plans) i.e. part-processing requirements on machines. Another important design issue is cell layout. Flow line cells seem to have several advantages over job shop cells: simplified materials flow, less need for internal sequencing/scheduling of jobs, less control problems in connection with the use of transfer batches, faster and easier defect detection, etc. The extent to which degree of automation is provided in each cell is also considered to be an important design issue[15].

\subsubsection{Operational issues}

The design of production planning and control procedures for Cellular Manufacturing Systems is considered to be an important operational issue. The first issue is whether new systems or philosophies of manufacturing are needed for cellular production control. The second issue is whether the formal control procedures such as MRP can be used for scheduling Cellular Systems. The production planning and control system does not necessarily be designed to operate on grouping principles, as a cell is an application of Group Technology (GT)[2].In most of the cases planning procedures depends on the type of cells involved, the operating pattern, the type of flow pattern in the cells, the linkages between cells, the cell sizes, the number and sizes of the part families assigned to the cells, the relative setup times, the degree of automation, etc.

\subsection{Cell Formation Techniques}

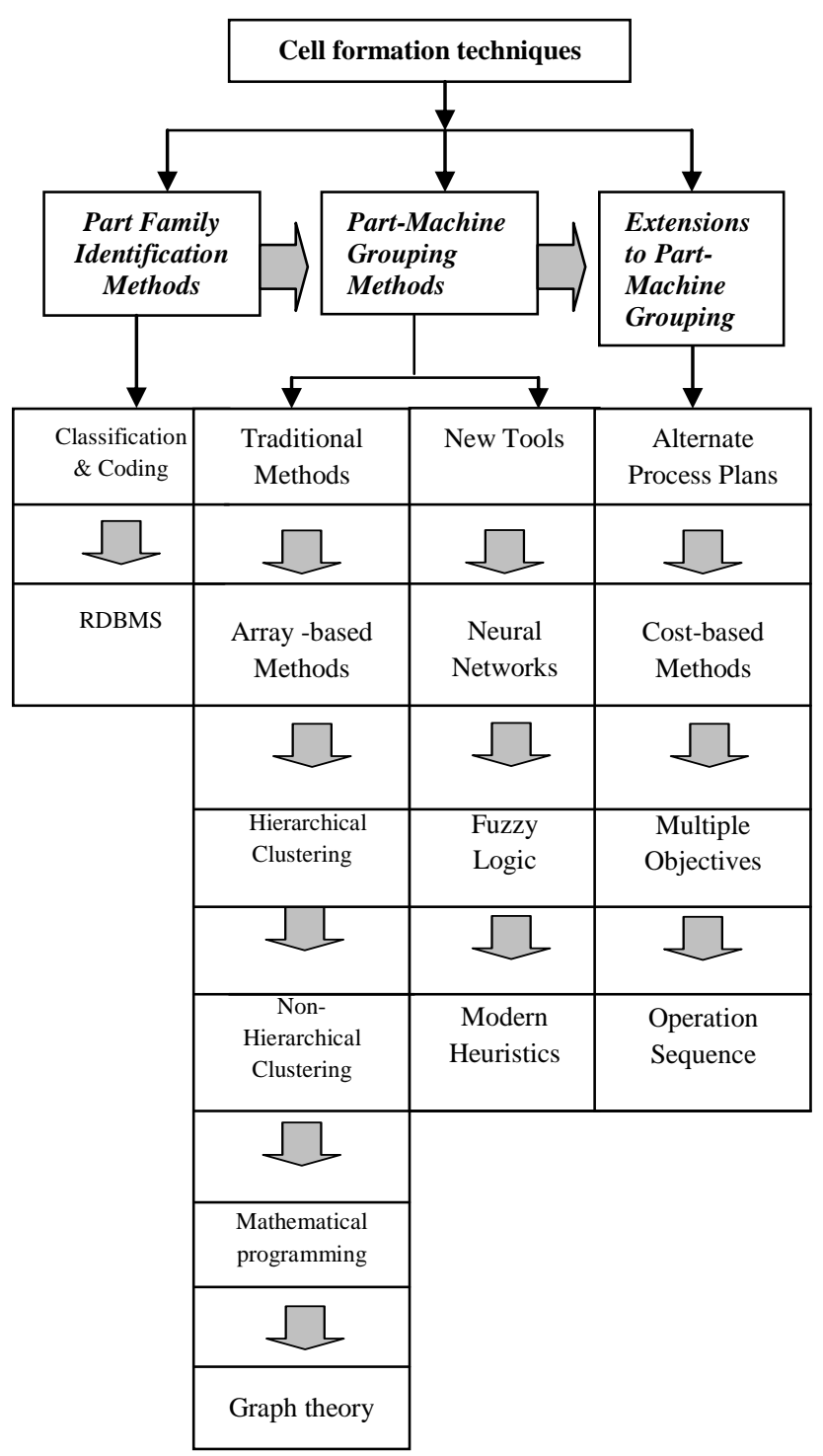

Fig 1: Cell Formation techniques

\subsubsection{Part family grouping}

(a) Classification and coding:

-The Design Oriented Approach (DOA): similarity in design/physical features like size, shape, presence of certain surfaces etc group the parts into families.

-The Product Oriented Approach (POA): the process route of each component is studied (from route cards) and those requiring similar operations are grouped together.

(b)Cluster analysis: group parts with common characteristics (resulting in a high similarity coefficient) together to form part families[7]. 


\begin{tabular}{|l|ll|}
\hline & $\bullet$ & Machine duplication \\
Minimum & $\bullet$ & Operation cost \\
cost of & $\bullet$ & Part subcontracting \\
& - & Inter-cell transportation \\
& - Intra-cell transportation \\
& - Space usage \\
\hline
\end{tabular}

\subsubsection{Machine grouping:}

Combinatorial analysis: machines are combined into groups and components into families based on some optimizing criteria. Many researchers have used LP formulation to solve machine component grouping problem.

The optimizing criteria may be minimizing costs in terms of intercellular movements, machine duplication etc.

\subsubsection{Machine-part grouping :}

(a)Line analysis: Flow of materials between machines inside the groups and with planning the best layout for machines.

(b)Factory flow analysis: Division into large groups of department size, and into large group of families of parts to be made in these departments.

(c)Group analysis: Division of the plant assigned to each department into groups and the division of the parts into associated [3].

Depending of market demand, number of cells gets finalized. When the demand increases, number of operators required for manufacturing the component also increases proportionately. Some time it is essential to run a machine for three shifts. In order to set a production at a particular range following points are important [4]:

1. Cell formation for different machines

2. Standard time required for a cell

3. Decision regarding running of a machine for one, two or three shifts

4. Once layout has been made no changes can be made in layout with increase in demand

5. Minimum walking time required between two machines in a cell, due to this standard time is reduced.

\subsection{Objectives}

\subsubsection{Conflicting objectives}

The three conflicting objectives considered in the present work are given as:

1.Minimization of total cost: Total cost comprises of machine investment cost and operating cost.

2.Minimization of intra-cell workload imbalance: The mean squared deviation, defined as the average of the squared differences between each individual machine utilization and the cell utilization, is the measure of load imbalance within a cell.

3. Minimization of inter-cell workload imbalance: This is the measure of variability of total workloads among the cells. It would make sense if cells were assumed as separate plants processing various parts of a variety of products, which will be sent to the final assembly area to assemble the products. Then the arrival times of these parts to the assembly area should be synchronized to prevent high-level inventories.
Another drawback of late arrivals is the increase in the flow time and decrease in the throughput rat [5].

\subsubsection{Classification of objectives}

Table 1. Classification of objectives

\begin{tabular}{|c|c|}
\hline $\begin{array}{l}\text { Minimum } \\
\text { amount } \\
\text { of }\end{array}$ & $\begin{array}{ll}\text { - } & \text { Duplicated machines } \\
\text { - } & \text { Inter-cell movements } \\
\text { - } & \text { Intra-cell movements } \\
\text { - } & \text { In-cell load unbalance } \\
\text { - } & \text { In-plant load unbalance } \\
\text { - } & \text { Parts dissimilarity } \\
\text { - } & \text { Skipping }\end{array}$ \\
\hline $\begin{array}{l}\text { Maximum } \\
\text { amount } \\
\text { of }\end{array}$ & $\begin{array}{ll}\text { - } & \text { Flexibility } \\
\text { - } & \text { Efficiency } \\
\text { - } & \text { Utilization } \\
\text { - } & \text { Cell independence }\end{array}$ \\
\hline $\begin{array}{l}\text { Minimum } \\
\text { deviation } \\
\text { From }\end{array}$ & $\begin{array}{l}\text { - } \text { Parts similarity } \\
\text { - } \quad \text { Machine available processing } \\
\text { - } \quad \text { Cell operator wages } \\
\text { - } \quad \text { Machine-operator skill matching } \\
\text { - } \quad \text { Minimum part movements } \\
\text { - } \quad \text { Opaximum investment cost } \\
\text { - } \quad \text { Set-up time } \\
\text { - Utilization } \\
\text { - } \text { Available funds }\end{array}$ \\
\hline
\end{tabular}

\subsection{Methodology}

The methodology to achieve the objectives is as follows: 1. Studying the existing layout

2.Identifying operation sequence \& elemental Operation time details for each machine.

3.Calculation of machine capacity for each machine.

4.Simulation of existing layout using suitable Simulation Software.

5.Developing suitable cellular layout for each Production line in cellular layout.

6.Calculation of manpower utilization for each Production line in cellular layout.

7.Determination of standard time for each production line in cellular layout. 
8.Determination of material handling route for each Production line in cellular layout..

9.Determination of WIP inventory and pallets requirement for each production line in cellular layout.

10.Analysis of Cellular layout - i.e. cost analysis.

11.Simulation of Cellular layout using suitable Simulation Software.

\subsection{Major contributions of the study}

The present system can be extended to take care of the following shortcoming:

1. Cell layout and intracellular movement issues can be considered for designing of Cellular Manufacturing Systems.

2. The system can be extended for accommodating new techniques like Knowledge based, Fuzzy clustering and Neural Network approaches.

3. Scheduling issues can be incorporated in design of CMS to bring additional savings in time and money [6].

4. Still much scope exists for considering more design attributes and developing better clustering techniques

5 Following factors play important role while designing CMS for existing plant layout [9]:

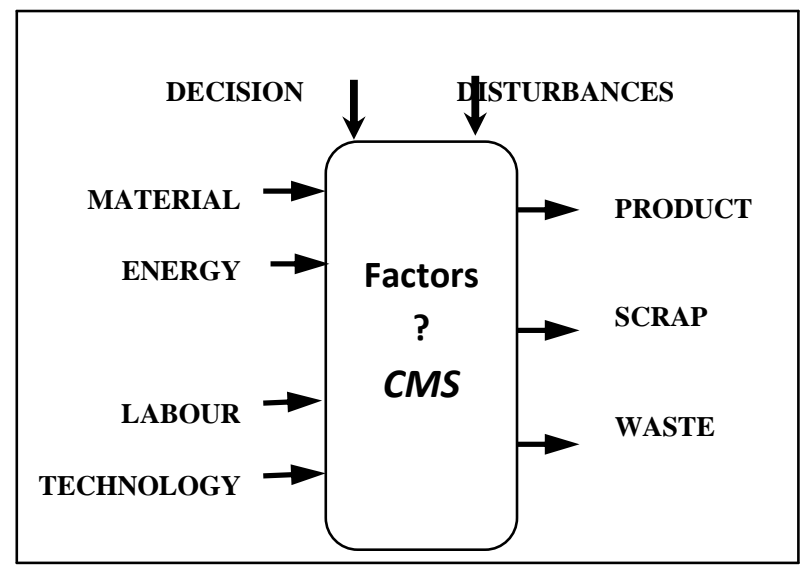

Fig.2 Factors Affecting CMS

Table 2. Factors of great importance to cell operation and implementation

\begin{tabular}{|c|l|c|}
\hline Sl. No. & \multicolumn{1}{|c|}{ Factors } & Importance \\
\hline $\mathbf{1}$ & Cell design and operation & 8 \\
1.1) Equipment placement /cell layout & 7 \\
1.2)Choice of equipment and MHS & 6 \\
1.3)Capacity balancing and production flow \\
1.4)Setup times/ tooling problems \\
1.5)Production planning/control system \\
1.6) Product design consideration \\
1.7) Purchased parts availability
\end{tabular} \mid \begin{tabular}{c}
1 \\
\cline { 2 - 3 }
\end{tabular}

\begin{tabular}{|c|l|c|}
\hline Sl. No. & \multicolumn{1}{|c|}{ Factors } & Importance \\
\hline $\mathbf{2}$ & Implementation factors & 8 \\
2.1)Planning for conversion & 8 \\
2.2)Education and training & 3 \\
2.3) Implementation time & 2 \\
2.4)Measurement and reward system & 1 \\
2.5)Top management support & $\mathbf{2 2}$ \\
\cline { 2 - 3 } & \multicolumn{2}{c}{ Total } \\
\hline
\end{tabular}

\begin{tabular}{|c|l|c|}
\hline Sl. No. & \multicolumn{1}{|c|}{ Factors } & Importance \\
\hline $\mathbf{3}$ & Human issue & 12 \\
& 3.1) Employee involvement & 3 \\
3.2)Operator/cell leader selection & 1 \\
3.3)Job rotation & $\mathbf{1 6}$ \\
\cline { 2 - 3 } & & \\
\hline
\end{tabular}

\section{CONCLUSION}

The primary focus of cell formation research is grouping parts into part families and machine into machine groups in order to create manufacturing cells such that one or more criteria are optimized. Considering multiple objectives makes the problem more complex and a better approach is required to solve for optimal solution. Also there is however a need to develop efficient approaches to obtain a set of non-dominated solutions considering a number of objectives to help the decision maker select satisfying solutions. Though considering alternate routes makes possible to form almost independent cells, the problem dealing with different process plans for each part makes the problem complex with so many hard variables and constraints. Better approach is required to solve the problem with large datasets. Only limited work has been done to address the important issue of incorporating manufacturing flexibility in the cell formation process. The current cell formation research deals with manufacturing flexibility, in selecting an alternate route for formation of independent cells. There is a need to deal with "cellular" manufacturing flexibility, as a strategic and operational competitive weapon and further, flexibility should be used as a design parameter in the cell formation process. There is a need to go beyond just grouping parts and machines. This can be achieved by adding workers and tools as third and fourth dimensions to parts and machines in the cell formation process. There is a need to evaluate and compare these approaches based on their applicability, availability, and practicability. These approaches should be tested to evaluate 
their performance in practical situations including realistic problem sizes and organizational considerations. The applicability of current cell formation approaches in an industrial context is also limited by the unavailability of interactive software programs supporting such an application. Hence, future research on cell formation methods should include documented and tested supporting software in order to facilitate industrial applications.

\section{REFERENCES}

[1] Askin R.G., Selim A. M. and Vakharia A. J.1997. 'A methodology for designing flexible cellular manufacturing systems ', IIE transactions , 29 : 599-610.

[2] Aryanezhada M.B. et al.2011. A new approach for cell formation and scheduling with assembly operation Structure, International Journal of Industrial Engineering Computations , 2:533-546.

[3] Arora Pawan Kumar et al.2011.' Cell Formation Techniques - A Study ', International Journal of Engineering Science and Technology ,3:1178-1182

[4] Barve S.B. et al.2011.'Research issues in Cellular Manufacturing System, International Journal of Applied Engineering Research,6:291-302.

[5] Choobineh F.1988. 'A framework for the design of cellular manufacturing systems', International Journal of Production Research, 26: 1161-1172.

[6] Chow S. W.and Ostap H.1993. 'A novel machine grouping and knowledge-based approach for cellular manufacturing, 'European Journal of Operational Research, 69: 357-372.

[7] Ghosh Tamal .et al.2011.'Coding and Classification Based Heuristic Technique for Workpiece Grouping Problems in Cellular Manufacturing System
'International Transaction Journal of Engineering, Management, \& Applied Sciences \& Technologies, 02:53-72.

[8] Huawei CHEN, WANG Aimin*, NING Ruxin, and SHAO Canxia .2011.' Layout Planning Technology of Cellular Manufacturing System Based on process interconnection Analysis 'CHINESE JOURNAL OF MECHANICALENGINEERING,24:1-11.

[9] Maynard .1971. Industrial engineering handbook, (Willian K.Hodson ,4th edition ,Mcgraw Hill) .

[10] Meyer F. E.1993. Plant layout and material handling (Englewood cliffis, prentice hall)

[11] Mohammad T. et al.2011.' Multi-objective group scheduling with learning effect in the cellular manufacturing system', International Journal of Industrial Engineering Computations, 2:617-630

[12] Singh N.1993.,'Design of cellular manufacturing systemAn invited review', European Journal of ProductionResearch,69:284-291.

[13] Song S. and Choi J.1993.'Optimization analysis of flexible manufacturing system', European Journal of OperationalResearch,69:399-412.

[14] Vakharia A. J. and Wemmerlov U.1990. 'Designing a CMS: A material flow approach based on operation sequence', IIE transaction, 22:84-97.

[15] Wemmerlov U. and Nancy L. H..1987.,'Research issues in CMS', International Journal of Production Research,25:413-431. 